\title{
HISTORIA UKRAINY W NAJNOWSZYCH ROSYJSKICH PODRECCZNIKACH DO HISTORII W ŚWIETLE ROSYJSKICH ROZWAŻÁ̃ NAD NARODEM
}

\section{The History of Ukraine in the Latest Russian History Textbooks in the Light of Russian Reflections on the Nation}

The article is devoted to the vision of Ukrainian history presented in the latest Russian secondary school history textbook published by Proswieshchenie. It also contains the analysis of selected events from the common Russian-Ukrainian history present in discourses concerning the concepts of the nation and the synthesis of Russian history. The textbook narrative is dominated by the myth of a brotherly nation and the imperialist vision of the history of the Russian state. According to the textbook narrative, Ukraine has subjectivity, although it is consistently diminished by the solution of the civilization approach.

Keywords: Ukraine, Russian history, history textbook, myth of a brotherly nation, concept of a civic nation, Historical and Cultural Standard, Saint Ruthenia, Sołowiow, 19th century historiography, Soviet historiography.

Rozpad Zwiazku Sowieckiego i utrata statusu mocarstwa spowodowały głęboki kryzys tożsamościowy w Rosji. Od 1991 roku Rosjanie próbują zrekonstruować swoją tożsamość narodowa, co jest zadaniem niezwykle trudnym, biorąc pod uwage wieloetniczny charakter Federacji Rosyjskiej oraz skomplikowaną imperialna historię ${ }^{1}$. Dezorien-

1 J.L. Rohlfing, The russian Sonderweg: a course of endless exclusion, Washington University Open Scholarship, https://openscholarship.wustl.edu/cgi/viewcontent.cgi?article $=2117 \&$ context $=$ etd [dostęp: 20 czerwca 2018] . 
tacja wokół pojęcia „rosyjskości” i nieumiejętność poradzenia sobie $z$ imperialnym dziedzictwem utrudnia rekonstrukcję tożsamości oraz stworzenie rosyjskiego narodu (ros. Hauuu) o charakterze politycznym, który by konsolidował wszystkie mniejszości etniczne zamieszkujace terytorium dzisiejszej Rosji i był oparty nie na pierwiastku etniczności, ale na imperatywie obywatelstwa oraz więzi z państwem. Balansowanie między polityczna koncepcja narodu a imperialną tożsamościa jest wyraźnie widoczne na przykładzie Ukrainy ${ }^{2}$, która wcią̇̇ zajmuje kluczowe miejsce $\mathrm{w}$ rosyjskiej mentalności oraz interesach geopolitycznych.

\section{DYLEMATY POSTSOWIECKIEJ TOŻSAMOŚCI ROSYJSKIEJ}

Pamięć historyczna rozumiana jako wizja przeszłości funkcjonująca w społecznej oraz indywidualnej świadomości jest jednym $z$ filarów tożsamości narodowej. Natomiast umiejętność kształtowania wspólnotowej pamięci i percepcji narodowej przeszłości jest instrumentem, dzięki któremu rządzący mogą wpływać na teraźniejszośćc ${ }^{3}$ i manipulować opinia publiczna, co doskonale obrazuje casus Rosji. Współczesna Rosja jako państwo wielonarodowe i wielokulturowe stanęła przed poważnym zadaniem konsolidacji swojego społeczeństwa wokół spójnej narracji historycznej, która w znacznej mierze jest kształtowana przez władze poprzez system edukacji szkolnej. Nie przypadkiem na posiedzeniu Rady ds. Stosunków Narodowościowych w 2013 roku prezydent Władimir Putin ogłosił ideę stworzenia jednolitej linii podręczników do historii dla szkół średnich. Jak zauważa Aleksiej Miller, problem bowiem nie leżał $\mathrm{w}$ różnorodności szkolnych podręczników, ale w podręcznikach używanych w autonomiach narodowych, które wnosiły elementy regionalizmu, tożsamość etniczną traktowały jak narodową, przeciwstawia-

\footnotetext{
2 Należy zaznaczyć, że nie tylko Rosja po rozpadzie ZSRS próbuje zrekonstruować swoją tożsamość narodową. Przed takim samym zadaniem stanęła również Ukraina, która poszukuje swoich korzeni i próbuje zrekonstruować swoją tożsamość historyczną. Podobnie jak w przypadku Rosji również ukraińska polityka historyczna ma charakter koniunkturalny. Na jej kształt w znacznej mierze wpływa nie tylko sytuacja wewnętrzna, ale także relacje ze swoim wschodnim sassiadem. Czynniki te powoduja, że historiografia po obu stronach granicy ma charakter silnie upolityczniony i zinstrumentalizowany. O dylematach ukraińskiej historiografii i rekonstrukcji ukraińskiej tożsamości narodowej oraz historycznej w sposób wyczerpujący traktuje monografia Tomasza Stryjka. Zob. T. Stryjek, Jakiej przeszłości potrzebuje przyszłość? Interpretacje dziejów narodowych $w$ historiografii $i$ debacie publicznej na Ukrainie 1991-2004, Warszawa 2007.

3 K. Kacka, Polityka historyczna: kreatorzy, narzędzia, mechanizmy działania - przykład Polski, w: Narracje pamięci. Między polityka a historia, red. K. Kącka, J. Piechowiak-Lamparska, A. Ratke-Majewska, Torun 2015, s. 64.
} 
jąc ją tożsamości rosyjskiej. ${ }^{4}$ Strach przed utratą suwerenności, podmiotowości oraz integralności terytorialnej ${ }^{5}$ mobilizuje rosyjskie władze do poszukiwania spoiwa (ros. ckpena) ${ }^{6}$, swoistej nadbudowy, która by się stała fundamentem dla rekonstrukcji rosyjskiej tożsamości narodowej. Na pierwszy plan wysuwa się więc problem utrzymania spójności mitu historycznego na terytorium Federacji Rosyjskiej (FR), gdyż polityka pamięci w poszczególnych republikach często stoi w sprzeczności $z$ zadaniem kształtowania tożsamości ogólnorosyjskiej ${ }^{7}$.

$Z$ drugiej jednak strony rosyjska tożsamość wciąż nie poradziła sobie $z$ dziedzictwem imperialnym. W tym kontekście ma ona charakter wielowymiarowy. Można w tym miejscu odwołać się do koncepcji Serhija Plokhyego, który twierdzi, że postsowiecka rosyjska tożsamość stanowi zbiór koncentrycznych kręgów. Jej rdzeń stanowi rosyjska etniczność, następnie pierwszy krag wokół rdzenia to tożsamość polityczna oparta na rosyjskim obywatelstwie, drugi to tożsamość wschodniosłowiańska, natomiast ostatni krąg obejmuje ludność rosyjskojęzyczną tzw. ruski mir (ros. pусский мир) ${ }^{8}$. W takim ujęciu rosyjskiej tożsamości Ukraina ze swoim dziedzictwem zajmuje kluczowe miejsce w dwóch $z$ czterech kręgów. I chociaż władze rosyjskie dostrzegaja potrzebę budowy tożsamości obywatelskiej jako warunek zachowania jedności państwa ${ }^{9}$, to w rzeczywistości jest ona definiowana w kategoriach "cywilizacyjnych" a nie „narodowych" ${ }^{10}$. Postsowiecka tożsamość rosyjska zasadza się bowiem na unikatowym kodzie kulturowym ${ }^{11}$, który określa granice mapy mentalnej Rosjan wychodzacej znacznie poza granice państwowe FR

4 A. Miller, Polityka pamięci $w$ Rosji. Rola czynników niepaństwowych, „Rocznik Instytutu Europy Środkowo-Wschodniej” 2015, t. 13, z. 2, s. 136, 138.

5 О. Сухова, О. Ягов, Имперская идентичность и формирование российской наиии: историографические аспекты проблемы, „Гуманитарные науки. История” 2015, $\mathrm{nr} 3(35)$.

6 Духовные скрепы - to rozpowszechniona w rosyjskim dyskursie publicznym fraza użyta po raz pierwszy przez prezydenta Władimira Putina podczas posłania skierowanego do Zgromadzenia Federalnego 12 grudnia 2012 roku. Zwrot ten oznacza duchowe wartości, które, zdaniem Putina, jednoczyły Rosję i czyniły ja silniejszą. Do owych duchowych „skriep” zalicza się: język rosyjski, rosyjską kulturę, wspólną ponadtysiącletnią historię. Idea ta jest uznawana za próbę wprowadzenia nowej wersji triady Uwarowa „prawosławie, samodzierżawie, ludowość". Zob. Послание Президента Федеральному Собранию, 12.12.2012, http:// kremlin.ru/events/president/news/17118 [dostęp: 14 października 2018].

7 A. Miller, Polityka pamięci..., s. 139.

8 S. Plokhy, Kwestia rosyjska. Jak budowano naród i imperium, Kraków 2019, s. 419.

9 Заседание международного дискуссионного клуба "Валдай", 19.09.2013, http:// kremlin.ru/events/president/news/ 19243 [dostęp: 31 maja 2019].

10 O. Malinowa, Idea wspólnej przeszłości $w$ Rosji postsowieckiej: wyobrażenia o narodzie $i$ imperialnym dziedzictwie, w: Dialog kultur pamięci $w$ regionie ULB, red. A. Nikzentaitis, M. Kopczyński, Warszawa 2014, s. 279.

11 В. Путин, Россия: национальный вопрос, 23.01.2012, http://www.ng.ru/politics/2012-01-23/1_national.html [dostęp: 31 maja 2019]. 
i obejmującej przede wszystkim Ukrainę oraz Białoruś. Problem Ukrainy, która jest głównym przedmiotem rozważań, jest złożony ze względu na jego światopoglądowy charakter. Jest on zwiazany $z$ przyznaniem Ukrainie oraz Ukraińcom prawa do historycznej, politycznej podmiotowości, która urzeczywistnia się w oddzielnej, niezależnej państwowości oraz niezależnym od rosyjskiego procesie historycznym ${ }^{12}$. Chociaż w 1991 roku Ukraina i Białoruś ogłosiły państwowo-narodowa niezależność, nie oznacza to, że przestały być integralnymi składowymi rosyjskiej świadomości narodowej i zakorzenionego w niej mitu wielkiego narodu rosyjskiego złożonego $z$ Wielkorusów, Małorusów i Białorusów ${ }^{13}$.

Poszukiwania odpowiedzi na pytanie, czym dzisiaj jest rosyjskość (czy włączyć w nią komponent ukraiński, białoruski) i w jakich kategoriach ją zdefiniować, staje się katalizatorem burzliwych dyskusji na polu naukowym oraz politycznym. $Z$ jednej strony nauka rosyjska stara się stworzyć paradygmaty, które mogłyby stać się fundamentem dla sformułowania komponentów ogólnonarodowej idei narodu obywatelskiego ${ }^{14} . Z$ drugiej zaś strony odpowiedzi na to egzystencjalne pytanie poszukuje współczesna elita władzy w Rosji, która poprzez prowadzenie polityki narodowościowej czy system szkolnictwa stara się konsolidować obywateli wokół ujednoliconej narracji historycznej.

Dyskusja, która rozgorzała wokół kwestii „stworzenia” narodu rosyjskiego $\mathrm{w}$ rozumieniu wspólnoty politycznej (ros. pосcuйcкая наиия), została niejako dopełniona opracowaniem i wprowadzeniem do rosyjskich szkół średnich w 2015 roku trzech ujednoliconych linii podręczników do nauki historii. W czasie ich przygotowywania doszło do aneksji Krymu i rozpoczęcia wojny we wschodniej Ukrainie, co w istotny sposób wpłynęło na treść podręczników, zostały one uzupełnione o elementy historii półwyspu oraz Noworosji ${ }^{15}$.

W jakim stopniu jednak postrzeganie narodowej historii zmieniło się we współczesnej Rosji w porównaniu z okresem carskim czy sowieckim, świadczy ujęcie historii Ukrainy w najnowszych podręcznikach. Czy władze rosyjskie i rosyjska historiografa dokonały rede-

${ }_{12}$ Г. Касьянов, На расходяшихся курсах. Исторические лабиринты Украины u Poccuu, „Global Affairs” 2018, nr 2, https://globalaffairs.ru/number/Na-raskhodyaschikhsya-kursakh-19487 [dostęp: 31 maja 2019].

${ }^{13}$ K. Świder, Rosyjska świadomość geopolityczna a Ukraina I Białoruś (po rozpadzie Zwiazku Radzieckiego), Warszawa 2015, s. 166.

${ }_{14}$ О. Жирнов, Теоретические модели становления гражданской наиии в современной России, „Вестник Саратовской государственной юридической академии” 2015, nr 6(107), s. 230.

${ }^{15}$ Częścia dawnej, stworzonej przez carycę Katarzynę II, guberni noworosyjskiej jest dzisiejszy ukraiński Donbas. Od rozpoczęcia wojny w Donbasie historia Noworosji stała się popularnym tematem w Rosji. 


\section{finicji wizji narodowego procesu historycznego? Czy po dwudziestu} siedmiu latach od rozpadu ZSRS i trwającego pięć lat konfliktu rosyjsko-ukraińskiego w stosunku do Ukrainy oraz jej historii w rosyjskiej świadomości zaszły jakieś zmiany? Ewolucję tę (lub jej brak) w bardzo dobry sposób oddają właśnie szkolne podręczniki do nauki historii, które prezentuja podejście zarówno historiograficzne, jak również polityczne (gdyż na kształt wszystkich podręczników - zwłaszcza do nauki historii - maja wpływ władze). W związu z powyższym celem artykułu jest zaprezentowanie wizji historii Ukrainy oraz relacji ukraińsko-rosyjskich w obecnie obowiazujacych podręcznikach do historii dla szkół średnich opracowanych pod redakcja Anatolija Torkunowa ${ }^{16}$ i opublikowanych przez oficynę wydawniczą Proswieszczenie ${ }^{17}$.

16 Anatolij Wasilewicz Torkunov (Анатолий Васильевич Торкунов) sowiecki i rosyjski dyplomata, $z$ wykształcenia historyk i politolog specjalizujacy się w stosunkach międzynarodowych. Od 1992 roku jest rektorem Moskiewskiego Państwowego Instytutu Stosunków Międzynarodowych, członkiem Rosyjskiej Akademii Nauk (RAN) oraz posłem nadzwyczajnym do Dumy Państwowej Federacji Rosyjskiej. Poza tym Torkunov jest współprzewodniczacym Polsko-Rosyjskiej Grupy do spraw Trudnych oraz zagranicznym członkiem Polskiej Akademii Nauk, http://www.torkunov.mgimo.ru/ [dostęp: 29 czerwca 2018].

$17 \mathrm{Na}$ wybór przez autorkę podręczników wydawnictwa Proswieszczenie (oprócz niego obecnie w Rosji podręczniki do historii wydaja jeszcze dwa inne wydawnictwa: Russkoje Słowo oraz Drofa) wpłyną fakt, że posiada ono wsparcie (nieoficjalne) rosyjskich władz, a także znacznie większy udział w rynku wydawniczym niż inne wydawnictwa.

Wydawnictwo Proswieszczenie (Oświecenie, ros. Просвещение) w okresie sowieckim było państwowym potentatem na rynku, zapewniając tym samym ideologiczna „poprawność" edukacji znajdującej się pod całkowita kontrolą państwa. Wydawnictwo było prawa ręką Ministerstwa Oświaty. Upadek ZSRS uwolnił jednak rynek wydawniczy, na którym pojawiła się konkurencja, a w okresie rządów Borysa Jelcyna szkoły mogły dowolnie korzystać z podręczników znajdujących się $\mathrm{w}$ spisie federalnym zatwierdzonym przez państwo. Jednak w 2011 roku rosyjski rząd wystawił wydawnictwo Proswieszczenie na sprzedaż w ramach planu prywatyzacyjnego. Wydawnictwo zostało kupione przez Olma Media Group posiadajaca znikomy, niespełna dwuprocentowy udział w rosyjskim rynku książkowym. Kilka miesięcy później firma ta sprzedała Proswieszczenie firmie zarejestrowanej na Cyprze. Finansowanie $(54,2 \mathrm{mln}$ \$) na zakup wydawnictwa pochodziło od SMP Bank, który jest kontrolowany przez Arkadija Rotenberga oraz jego brata Borysa. Arkadij Rotenberg jest wieloletnim przyjacielem Władimira Putina oraz gospodarczym potentatem. Następnie kredyt był refinansowany przez Gazprombank (77,1 mln \$). W 2013 roku, dwa lata po prywatyzacji wydawnictwa, Arkadij Rotenberg wystapił w oficjalnej roli jego prezesa. Proswieszczenie jest nieoficjalnie wspierane przez Ministerstwo Oświaty i pomimo istniejacej teoretycznie konkurencji posiada obecnie pozycje monopolistyczna na rynku wydawniczym. Zdaniem Michaiła Morozowskiego, redaktora naczelnego czasopisma „Book Business”, tylko w pierwszych 7 miesiącach 2014 roku rosyjskie szkoły wydały 187 milionów dolarów na zakup podręczników. Wydawnictwo Proswieszczenie wygrało 60-70 proc. wszystkich kontraktów. Dostarcza ono także około 80 proc. podręczników wysyłanych przez Kreml do anektowanego Krymu. Zob. J. Becker, S. Lee Myers, Putin's friend profits in purge of schoolbookks, https://www. nytimes.com/2014/11/02/world/europe/putins-friend-profits-in-purge-of-schoolbooks. html [dostęp: 23 października 2018]. Istotny jest również fakt, że podręczniki do nauki historii tego wydawnictwa jako jedyne posiadaja logo (atest) Rosyjskiego Towarzystwa Historycznego, które wraz z Ministerstwem Oświaty promuje te podręczniki. Zob. На обложках учебников "Просвещения" по отечественной истории появится логотип Российского исторического общества, https://www.prosv.ru/news/show/1409.html [dostęp: 23 października 2018]. 


\section{PRZYCZYNY REFORMY}

Na wstępie rozważań nad wizją ukraińskiej historii w rosyjskich podręcznikach na uwage zasługuje sama reforma nauczania tego przedmiotu. W 2015 roku w Rosji wprowadzono trzy linie podręczników do nauki historii w szkole średniej. Te funkcjonujace do tej pory zostały wycofane $z$ rynku wydawniczego i po wprowadzonej reformie nauczyciele maja obowiąek korzystania tylko $z$ podręczników obecnie obowiazujacych ${ }^{18}$.

Inicjatywa rosyjskiego prezydenta oraz kładziony przez niego nacisk na ujednolicenie podręcznikowej narracji historycznej pozbawionej sprzeczności i prezentującej wyważona, uznawana powszechnie, kanoniczną wizję dziejów Rosji, odzwierciedla „troskę" o jednolitość kształcenia historycznego, które, jak uważa głowa państwa, ma za zadanie konsolidację wieloetnicznego społeczeństwa rosyjskiego. Jednocześnie prezydencka propozycja jest odpowiedzią na krytykę dotychczasowego systemu kształcenia w zakresie historii. Zdaniem wielu krytyków, głównym mankamentem tego systemu była monoetniczna koncepcja dziejów państwa rosyjskiego, podczas gdy wieloetniczny charakter mieszkańców wymagał polietnicznego spojrzenia na historię. Drugim często pojawiającym się zarzutem jest, zdaniem krytyków systemu, pisanie historii państwa przez rosyjskich historyków wykorzystujących „ruski materiał" - to znaczy zbytnie koncentrowanie się na historii etnicznych Rosjan, przy jednoczesnym marginalizowaniu dziejów zamieszkujących FR mniejszości etnicznych. Dlatego, zdaniem krytyków wcześniej obowiazujacej narracji historycznej w szkolnych podręcznikach oraz zwolenników „centralizacji” dyskursu historycznego, jednolity charakter wizji dziejów wielonarodowego państwa rosyjskiego posiada potencjał konsolidacji wieloetnicznego społeczeństwa i może stać się czynnikiem cementującym jego integralność terytorialną ${ }^{19}$.

Kwestia dominacji etnicznych Rosjan przy jednoczesnej marginalizacji innych żywiołów narodowych jest w Rosji rzeczywiście żywotnym problemem utrudniającym proces narodowotwórczy. Jak zauważa Rustem Gibadullin, postępujący po rozpadzie Związku Sowieckiego proces rekonstrukcji narodu rosyjskiego odbywa się wyłącznie

18 Концепция нового учебно-методического комплекса по Отечественной истории, https://historyrussia.org/proekty/kontseptsiya-novogo-uchebno-metodicheskogo-kompleksa-po-otechestvennoj-istorii.html [dostęp: 29 czerwca 2018].

19 В. Газизумлович, О кониепиии общенациональной истории России, „Научный журнал КубГАУ” 2016,nr 118(04), s. 3-5, https://cyberleninka.ru/article/n/o-kontseptsiiobschenatsionalnoy-istorii-rossii [dostęp: 29 czerwca 2018]. 
w oparciu o ruską etniczną samoświadomość i tradycyjne patriotyczne wartości ruskiego narodu. „Nieruscy” Rosjanie ${ }^{20}$ nie identyfikuja się, jego zdaniem, z państwem rosyjskim. W ramach procesu wyłaniania się „nowej” Rosji konstytuuje się raczej monokultura niż efektywny model multikulturalizmu. Zdaniem Gibadullina w polityce narodowościowej Moskwy można zaobserwować niebezpieczną tendencję do ograniczania etnokulturowej działalności nieruskich grup etnicznych, które sa postrzegane jako przeszkoda na drodze rozwoju jednolitego narodu, a w końcowym rozrachunku jako źródło niebezpiecznego separatyzmu zagrażającego integralności Rosji ${ }^{21}$.

Opracowanie nowych podręczników do historii $z$ uwzględnieniem dziejów innych grup etnicznych wchodzacych w skład Federacji Rosyjskiej jest więc odpowiedzia na stawiane zarzuty i w zamierzeniu jej twórców ma stanowić panaceum na wyżej zaprezentowany problem.

W celu opracowania nowych podręczników do historii dla szkoły średniej została powołana grupa robocza Rosyjskiego Towarzystwa Historycznego (RTH), która miała się zająć przygotowaniem Koncepcji nowego szkolno-metodologicznego kompleksu historii ojczystej (później zwanej Koncepcja), która stała się następnie bazą dla nowych podręczników. Do rosyjskich szkół trafiła ona w 2014 roku. To na jej podstawie nauczyciele historii mieli prowadzić zajęcia, posiłkując się podręcznikami wówczas obowiązującymi, które poddawane stopniowo „naukowym” ekspertyzom były systematycznie wycofywane ze szkół, jeżeli uznano je za niespełniające wymogów Koncepcji ${ }^{22}$.

Ostatecznie w wyniku reformy do federalnego spisu podręczników zostały włączone trzy linie wydawnicze. Były to: linia wydawnictwa Proswieszczenie (ros. Просвещение) pod redakcja Anatolija Torkunowa

${ }^{20} \mathrm{~W}$ języku rosyjskim należy rozróżnić dwa przymiotniki - rosyjski (росcuŭckuŭ) oraz ruski (русскиŭ). Pierwszy z nich (w dużym uproszczeniu) określa wszystko to, co jest związane $z$ państwem rosyjskim, nawiązuje do wielonarodowej państwowości rosyjskiej - Rosjanin to obywatel Federacji Rosyjskiej (bez względu na pochodzenie etniczne). Natomiast drugi z nich określa przynależność do szeroko pojętej kultury „ruskiej”, nawiązuje do wspólnego kodu cywilizacyjno-kulturowego, który łączy Rosjan, Ukraińców oraz Białorusinów jako protoplastów duchowej spuścizny Rusi Kijowskiej, połączonych wspólnym rodowodem, językiem oraz wiara prawosławna. Zatem nie każdy Rosjanin będzie jednocześnie Ruskim, ale jednocześnie nie-Rosjanin (np. Ukrainiec, czy Białorusin) może być Ruskim. Zob. Idieii $w$ Rossii. Idee $w$ Rosji. Ideas in Russia. Leksykon rosyjsko-polsko-angielski, t. 8, red. J. Dobieszewski, Łódź 2014, s. 362.

${ }^{21}$ Р. Гибадумин, Постсоветский дискурс нации как проблема, „ВАасть” 2010, nr 1, s. 76, https://cyberleninka.ru/article/n/postsovetskiy-diskurs-natsii-kak-problema-mezhetnicheskogo-edinstva-rossii [dostęp: 31 maja 2019].

22 Концепция нового учебно-методического комплекса по Отечественной истории, https://historyrussia.org/proekty/kontseptsiya-novogo-uchebno-metodicheskogo-kompleksa-po-otechestvennoj-istorii.html [dostęp: 29 czerwca 2018]. 
obejmująca podręczniki od klasy 6 do 10 szkoły średniejej ${ }^{23}$, podręczniki wydawnictwa Drofa (ros. Дpoфpa) także przeznaczone dla klas 6-10 pod redakcja I. Andriejewa, I. Fiedorowa, a także podręczniki od 6 do 9 klasy wydawnictwa Ruskoje Słowo (ros. Русское Слово) opracowane pod redakcja J. Pietrowa ${ }^{24}$.

\section{DYSKUSJE WOKÓŁ POJĘCIA NARODU}

Nacisk (przynajmniej w sferze werbalnej), który obecnie w Rosji kładzie się na budowę narodu obywatelskiego, a którego jednym ze „stymulatorów" ma być ujednolicona szkolna narracja historyczna, świadczy o pewnej ewolucji pojęcia państwa i narodu w rosyjskiej świadomości. Pojęcie narodu obywatelskiego, które obecnie cieszy się popularnościa, nie zostało jednak umieszczone w nadal obowiąującej Konstytucji Federacji Rosyjskiej z 1993 roku. Zamiast tego pojęcia funkcjonuje w niej konstrukcja „wielonarodowego narodu”25. Normatywne podstawy pojęcia narodu o charakterze politycznym opracowano w Strategii państwowej polityki narodowościowej Federacji Rosyjskiej do 2025 roku. W dokumencie tym państwo rosyjskie jest zdefiniowane jako wspólnota narodów, której jądrem jest „ruski lud” (ros. Hapod). Kulturowym spoiwem państwa jawi się wspólny kulturowy (cywilizacyjny) kod wytworzony dzięki zachowaniu rosyjskiej (ros. pycckas) kultury i języka ${ }^{26}$.

${ }^{23}$ W 2001 roku powrócono w Rosji do jedenastoklasowego programu szkolnego. Obecnie funkcjonują trzy stopnie kształcenia: czteroletnie kształcenie początkowe, pięcioletnie nauczanie podstawowe oraz dwuletnie kształcenie średnie lub tzw. średnie pełne. Odebranie dziewięcioletniej edukacji pozwala na zdobycie tzw. średniego niepełnego wykształcenia, natomiast jedenastoletnia szkoła gwarantuje zdobycie średniego pełnego wykształcenia i kończy się Jednolitym Egzaminem Państwowym (Еди́ный госуда́рственный экза́мен - ЕГЭ) - odpowiednikiem polskiej matury. Zob. Особенности школьной системы образования в нашей стране, https://edunews.ru/education-abroad/sistema-obrazovaniya/shkolnoe.html [dostęp: 8 lipca 2018]. W roku szkolnym 2016/2017 (wraz z przyjęciem koncepcji i standardu oraz wprowadzeniem do szkół nowych podręczników) rozpoczął się w Rosji również proces odchodzenia od koncentrycznego systemu nauczania historii w szkołach, zgodnie $z$ którym cały kurs był realizowany w szkole podstawowej w klasach 5 (6) - 9, a następnie powtarzany w klasach dziesiątej i jedenastej. Obecnie następuje przejście do systemu liniowego, który zakłada rozłożenie całego materiału na klasy od 5 (6) do 11. Zob. В. Котенев, А. Кузьмин, особенности перехода на линейную систему школьного исторического образования в условиях реализаиии требований историко-культурного стандарта, s. 3, https: / / суberleninka.ru/article/n/osobennosti-perehoda-na-lineynuyu-sistemu-shkolnogo-istoricheskogo-obrazovaniya-v-usloviyah-realizatsii-trebovaniy-istoriko [dostęp: 8 lipca 2018].

24 Концепция нового учебно-методического комплекса по Отечественной истории, https://historyrussia.org/proekty/kontseptsiya-novogo-uchebno-metodicheskogo-kompleksa-po-otechestvennoj-istorii.html [dostęp: 29 czerwca 2018].

25 Конституция Российской Федерации, статья 3, 12 декабря 1993 г., www.constitution.ru/10003000/10003000-3.html [dostęp: 30 czerwca 2018].

26 Указ Президента Российской Федераиии о стратегии наииональной политики Российской Федераиии на период до 2025 года, Москва 19.12.2012, s.3, http://www. minnac.ru/res_ru/0_hfile_1118_1.pdf [dostęp: 1 lipca 2018]. 
Dyskusja na temat potrzeby stworzenia narodu politycznego (obywatelskiego) i obecność tego modelu w dokumentach o charakterze państwowym oraz nawiąanie do niego w Koncepcji nowego szkolno-metodologicznego kompleksu historii ojczystej i czerpanie $z$ niej podczas prac nad nowymi podręcznikami do nauki historii świadczy o próbie budowania obywatelskiej tożsamości, zgodnie $z$ która naród rosyjski tworza obywatele Federacji Rosyjskiej ${ }^{27}$. Niemniej jednak jest to model problematyczny, ponieważ jego zwolennicy stoją przed trudnym pytaniem, w jaki sposób traktować imperialną trajektorię dziejów rosyjskiego państwa, które przez epoki włączało w swoje granice wiele narodów funkcjonujacych obecnie w ramach niepodległych państw i reprezentujacych konkurencyjne wobec rosyjskiej narracje historyczne oraz posiadajacych własne pamięci - wymownym przykładem jest naród ukraiński. Skrajna propozycja rozwiąania tej kwestii stanowia poglądy Rustema Wachitowa - rosyjskiego filozofa, który naród obywatelski uważa tylko za modyfikację narodu etnicznego uosabiająca imperialną rodzinę narodów. Jego zdaniem, należy odtworzyć imperium, które historycznie funkcjonowało na przestrzeni wieków jako państwo. Tym samym głosi on ideę odrodzenia imperium jako narodowo-państwowego bytu ${ }^{28}$.

W teorii rosyjskiego narodu kluczowe znaczenie maja dwie główne, wzajemnie ścierające się koncepcje - podejście Ramazana Abdułatipowa oraz Walerija Tiszkowa. Dla pierwszego naród jest tworem w pełni realnym $^{29}$, dla drugiego stanowi fikcję będącą tylko formą samookła-

27 J.L. Rohlfing, The russian..., s. 2.

28 О. Жирнов, Теоретические..., s. 233.

29 О. Неменский, Российская наиия vs. Русский народ, „Вопросы национализма” 2012, nr 1(9), s. 83. Należy zaznaczyć, iż Oleg Niemienskij jest rosyjskim historykiem reprezentujacym skrajne stanowisko wobec Ukrainy. Jest wykładowca w Rosyjskim Instytucie Badań Strategicznych Moskiewskiego Państwowego Uniwersytetu oraz Instytutu Słowianistyki Rosyjskiej Akademii Nauk, ale jednocześnie współpracuje i publikuje swoje artykuły na stronie skrajnie nacjonalistycznego portalu internetowego „Sputnik i Pogrom” (Спутник и Погром). Portal ten popiera chociażby przyłączenie Krymu i Donbasu do Rosji. Zgodnie $z$ zapewnieniami redakcji portalu setki internautów sympatyzujących z nim wyjechało walczyć w Donbasie. Portal zbierał również środki na zakup uzbrojenia w celu „wyzwolenia” Donbasu. Zob. https://sputnikipogrom.com [dostęp: 19 października 2018]. Publikując swoje artykuły na tym portalu, Niemienskij propaguje skrajnie negatywne stanowisko wobec Ukrainy. W jednym ze swoich artykułów zamieszczonych na stronie „Sputnika i Pogromu” autor nazywa ukraińskość nie etnosem, ale partią polityczną. Zob. О. Неменский, Вопросы наиионализма: украинство как политический проект, https: / / sputnikipogrom.com/nationalism/62132/ukr-project/ [dostęp: 19 października 2018]. Niemienskij twierdzi, że: „[...] na Ukrainie jest tylko jedna ideologia i ją w pełni wyrażaja radykalni ukraińscy nacjonaliści - ideologia integralnego nacjonalizmu. Innych ideologii, które byłyby zaproponowane społeczeństwu, innych idei oprócz tej ideologii po prostu nie ma...Władza faktycznie znajduje się w rękach radykalnych nacjonalistów, którzy zawładnęli dyskursem...W Ukrainie rozpoczyna się okres przedwyborczy i Poroszenko ze swoja 
mywania - społeczeństwo jest okłamywane przez elitę dążącą do sprawowania nad nim kontroli ${ }^{30}$.

W latach dziewięćdziesiątych XX wieku Tiszkow należał do grona czołowych orędowników obywatelskiej koncepcji rosyjskiej tożsamości. W jego zamyśle rosyjski naród obywatelski miał obejmować wszystkich obywateli FR bez względu na pochodzenie etniczne. Jego spoiwem miały być wspólne wartości oraz instytucje, a jego symbole miały pochodzić nie $z$ przeszłości imperialnej, ale rewolucji liberalnej. Jednak model Tiszkowa napotkał poważne przeszkody - jedną $z$ nich było użycie siły przez Jelcyna w 1993 roku do stłumienia buntu narodowców i komunistów. Wówczas, w obliczu narastających nastrojów separatystycznych na Północnym Kaukazie, idea ta nie spotkała się ze zbyt dużym entuzjazmem ${ }^{31}$.

W latach dziewięćdziesiątych na fali niewielkiego zainteresowania koncepcja narodu obywatelskiego powstawały alternatywne idee. Na uwage zasługuje chociażby koncepcja Władimira Kabuzana, który zaproponował mentalną mapę Rosji, rozumianej jako byt etniczno-kulturowy, która ze względu na duże skupiska Rosjan oraz ludności rosyjskojęzycznej obejmowała także wschodnią i południową Ukrainę, północny Kazachstan czy część Łotwy i Estonii. Kabuzan głosił tezę o przyłączeniu tych terenów do Rosji lub ustanowieniu tam jednostek autonomicznych posiadających szczególny status językowy oraz kulturowy ${ }^{32}$.

Rozumienie rosyjskiego procesu historycznego w kategoriach trajektorii dziejów państwa rosyjskiego, które od zarania było tworem wieloetnicznym i multikulturowym, postulowanie tym samym, że jego historia stanowi integralna część dziejów narodów ów organizm państwowy tworzacych, jest formułowaniem programu stworzenia narodu rosyjskiego na bazie obywatelskiego nacjonalizmu jako nowej imperialnej „rodziny narodów” - tak twierdzi Sergiej Kara-Murza. Jednak podczas gdy dominacja „ruskiego” nacjonalizmu może prowadzić „tylko” do nowego zbierania ziem ruskich, to rosyjski nacjonalizm może być rzeczywiście skłonny do wysuwania pretensji wobec całego terytorium byłego imperium ${ }^{33}$.

drużyną zainteresowany jest poparciem ukraińskich nacjonalistów". Zob. О. Неменский, На Украине только одна идеология - идеология интегрального национализма, https:// riss.ru/smi/52982/ [dostęp: 19 października 2018].

${ }_{30}$ В. Тишков, О наиии, http://www.valerytishkov.ru/cntnt/publikacii3/publikacii/ o_nacii1.html [dostęp: 8 lipca 2018].

${ }^{31}$ S. Plokhy, Kwestia rosyjska..., s. 381-382.

32 Ibidem, s. 386.

33 О. Неменский, Российская..., s. 86. 
Obecność w dyskursie publicznym i naukowym koncepcji narodu obywatelskiego paradoksalnie nie oznacza całkowitej rezygnacji $z$ innych modeli definiowania rosyjskiego narodu oraz szlaku imperialnych dziejów państwa rosyjskiego, o czym najlepiej świadczy podejście do ukraińskiej historii. W rosyjskim dyskursie popularnościa cieszy się także podejście cywilizacyjne. Konstrukcja ta jest chętnie stosowana przez autorów artykułów, szkolnych podręczników, monografii, wykładowców uczelni wyższych. Jądrem tej koncepcji jest teza o unikalności i samowystarczalności rosyjskiej cywilizacji. Na ową wyjątkowość składa się „zmodyfikowana” i „skrojona na miarę” współczesnych wyzwań politycznych czy społecznych triada Uwarowa obejmująca współcześnie takie wartości, jak: prawosławie, wspólnotowość, soborowość, państwowość ${ }^{34}$. Ideologiczny mit unikalności i duchowej wyższości rosyjskiej cywilizacji czerpie ze źródeł Świętej Rusi, a na jego ukształtowanie wpłynęło wiele czynników: przyrodniczo-geograficzne środowisko, ekonomiczno-społeczne układy, państwowość, mentalność, wyznanie, współistnienie $z$ innymi kulturami i grupami etnicznymi ${ }^{35}$.

Konstrukcja Sonderweg, czyli szczególnej drogi w historiografii rosyjskiej ${ }^{36}$, jest także obecna w podręcznikach do nauki historii wydawnictwa Proswieszczenie. Podręczniki te stanowia kombinacje dwóch koncepcji historiograficznych - historia rosyjska jest historia państwa, ale państwa, które stanowi jednocześnie oddzielną, wyjątkową cywilizację będąca kwintesencja „ruskiej” duchowości czerpiącej ze źródeł Świętej Rusi. Za Wadimem Cymburskim Rosję można określić mianem „cywilizacyjnej wyspy” (ros. Остров Россия) ${ }^{37}$. Podejście cywilizacyjne jest szczególnie ważne $\mathrm{w}$ omawianych podręcznikach, gdyż to właśnie ono w istotny sposób wpływa na postrzeganie Ukraińców w kategoriach „bratniego narodu” połączonego $z$ Rosjanami więzami krwi oraz wiary, a także stanowiacych wraz $z$ nimi i Białorusinami trzon ruskiej cywilizacji, tym samym powoduje to odmawianie im historycznej autonomii.

34 Cechy te po części odpowiadaja wartościom, które promowała triada Uwarowa z 1833 roku: „prawosławie, samodzierżawie, ludowość”. Oczywiście elementy nieprzystające do współczesności, jak samodzierżawie zostały usunięte i zastąpione innymi „duchowymi wartościami” spajającymi naród rosyjski.

35 В. Согри, Теоретические подходы к российской истории кониа ХХ века, „Общественные науки и современность” 1998, nr 4, s. 132.

36 J.L. Rohlfing, The russian..., s. 1.

37 В. Цымбурский, Остров Россия. Циклы похищения Европы (Большое примечание К „Острову Россия”), http://old.russ.ru/antolog/inoe/cymbur.htm [dostęp: 19 października 2018]. 


\section{UKRAINA W „PUTINOWSKIEJ” NARRACJI PODRECZNIKOWEJ}

Burzliwe dyskusje, jakie toczą się w Rosji wokół pojęcia narodu oraz konstruowania syntez dziejów narodowych, a także dezorientacja wokół pojęcia „rosyjskości”, znalazły wyraz także w linii podręczników wydawnictwa Proswieszczenie. Podręczniki te sa de facto hybrydą idei dziewiętnastowiecznej historiograficznej szkoły państwowej, za której głównego reprezentanta uznaje się Sergieja Sołowiowa i jego wielotomowe dzieło Historia Rosji od najdawniejszych czasów, oraz sowieckiej tradycji historiograficznej. Narracja podręcznikowa próbuje łączyć obie tradycje i zapożycza $z$ nich wygodne - odpowiadające obecnej sytuacji wewnętrznej oraz celom politycznym ekipy rządzącej, a także koniunkturze międzynarodowej - wątki, idee legitymizujące poczynania rosyjskiego „Olimpu władzy”. Splata dwie wydawałoby się sprzeczne, nawzajem wykluczające się tradycje historiograficzne i w najpełniejszy sposób odzwierciedla współczesna rosyjska politykę historyczną, która jawi sie „hybryda carsko-sowiecka”"38. Czerpanie $z$ dorobku obu historiografii ma istotne znaczenie $\mathrm{w}$ kontekście postrzegania historii Ukrainy, która wciąż zajmuje relewantne miejsce w rosyjskiej historiografii. Świadczy o tym chociażby zasób wiadomości i wątków ukraińskiej historii poruszanych w podręcznikach wydawnictwa Proswieszczenie. Ukrainie poświęcono w nich znacznie więcej miejsca niż na przykład „bratniej” Białorusi. W związku z powyższym na potrzeby artykułu autorka dokona analizy informacji poświęconych ukraińskiej historii zawartych w podręcznikach tegoż wydawnictwa przeznaczonych dla klas od szóstej do dziesiątej szkoły średniej.

Jeżeli chodzi o umiejscowienie wątków poświęconych historii narodu ukraińskiego oraz terytoriów dzisiejszej Ukrainy w podręcznikach opracowanych pod redakcja A.W. Torkunowa, znajduja się one $\mathrm{w}$ większości w oddzielnych rozdziałach poświęconych historii narodów Rosji. Rozdziały te są w większości przeznaczone do pracy samodzielnej. Materiał ten lokalizuje naród ukraiński wśród innych narodów Rosji - Rosjan, narodów Powołża, Syberii, Kaukazu ${ }^{39}$. Następnie w XVIII wieku do spisu tego dołaczyły narody Kazachstanu, Kałmu-

${ }^{38} \mathrm{~W}$ polskim dyskursie naukowym na uwagę zasługuje interesujace studium wspó1czesnej rosyjskiej polityki historycznej wraz z jej rysem historycznym Wojciecha Materskiego. Zob. W. Materski, Od Cara do „Cara”. Studium rosyjskiej polityki historycznej, Warszawa 2017.

39 История России. 6 класс. Уиебник для общеобразовательных организаиий, red. А.В. Торкунов, ч. 2, Просвещение, Москва 2016, s. 81-85; 113-120. 
cji oraz Dalekiego Wschodu ${ }^{40}$. Wątki ukraińskich dziejów stanowia w podręcznikach część wewnętrznej historii państwa rosyjskiego Ukraina po wejściu w skład Imperium Rosyjskiego w wyniku Rady Perejasławskiej przestała być traktowana jako podmiot „zagraniczny”. Zgodnie $z$ narracja podręcznikowa naród ukraiński posiada, co prawda, etniczna autonomię, chociaż jest ona pomniejszana ze względu na postrzeganie jego dziejów przez pryzmat mitu „bratniego narodu”. W narracji podręcznikowej Ukraina traci podmiotowość w sensie państwowym - od 1654 roku staje się częścią, jedną $z$ wielu składowych, państwa rosyjskiego, a jej historia postrzegana jest w kategoriach wewnętrznych Imperium Romanowów.

Pierwsza kwestia historyczna, która rodzi spory między Rosja a Ukraina, jest mit Rusi. Sam fakt poświęcenia historii państwa staroruskiego praktycznie całego podręcznika dla klasy szóstej ${ }^{41}$ świadczy, że wciąż stanowi ona dla Rosjan mit założycielski, który jest przedmiotem sporu i rywalizacji między Moskwą a Kijowem. Rosjanie niewątpliwie roszczą sobie prawo do tej spuścizny, która uważają za swoje dziedzictwo. Fundamentalne znaczenie w tym aspekcie posiada przyjęcie przez św. Włodzimierza chrztu, które było nie tylko aktem o charakterze eklezjalnym, ale i politycznym, a nawet cywilizacyjnym ${ }^{42}$.

W tym kontekście autorzy kompendium czerpią ze spuścizny Sołowiowa, który wyraźnie podkreślał europejskie pochodzenie Rosji, dopełniając je dodatkowo kulturową wyjątkowościa i ekskluzywnościa wynikająca $z$ położenia państwa carów na styku dwóch cywilizacji: europejskiej i azjatyckiej. Zdaniem Sołowiowa, głównym zadaniem rosyjskiej historiografii było jednak znalezienie miejsca i wpisanie się w historię cywilizacji europejskiej. Był przekonany, że Rosja podąży ścieżka postępu przetarta już przez kraje Europy Zachodniej³. Pierwszym krokiem w tym kierunku był chrzest, który otworzył Rusi drzwi do Europy. Jednocześnie w tekście położono akcent na miejsce chrztu św. Włodzimierza - Chersonez jawi się jako źródło duchowej spuścizny Rosjan ${ }^{44}$. Unikalność i znaczenie Chersonezu w rosyjskiej historii

40 История России. 8 класс. Учебник для обиеобразовательных организаиий, red. А.В. Торкунов, ч. 2, Просвещение, Москва 2016, s. 101-104.

41 История России. 6 класс. Учебник для обиеобразовательных организаиий, red. А.В. Торкунов, ч. 1, Просвещение, Москва 2016, s. 10-128, ч. 2, s. 4-116.

42 Ibidem, s. 49-54.

43 A. Siljak, Christianity, science, and progres in Sergei M. Solov'ev's history of Russia, $\mathrm{w}$ : Historiography of imperial Russia. The profession and writing of history in a multinational state, ed. Th. Sanders, London-New York 1999, s. 222.

44 История России. 6 класс. Учебник для обиеобразовательньх организаиий, red. А.В. Торкунов, ч. 1 , s. 52 . 
podkreśla często sam prezydent Putin. Na przykład podczas spotkania $z$ uczonymi w rezerwacie Chersonez Taurydzki powiedział:

Chersonez stał się baza i podstawa umocnienia ruskiej państwowości, należy z niego stworzyć „rosyjska Mekkę”. Nie chodzi o to, że tutaj [w Chersonezie] książę Włodzimierz przyjął chrzest, ale o to, że wraz $z$ tym wydarzeniem rozpoczał się proces umocnienia rosyjskiej państwowości...Miejsce to ma unikatowe znaczenie dla naszego państwa, naszego narodu i naszej państwowości ${ }^{45}$.

W kontekście aneksji Krymu jego słowa mają charakter symboliczny.

Na V-VI wiek autorzy podręcznika dla klasy szóstej datuja wydzielenie sie grupy Słowian wschodnich, do których zgodnie zaliczaja Rosjan, Ukraińców oraz Białorusinów ${ }^{46}$. W ten sposób autorzy podtrzymują tezę o wspólnych korzeniach plemion wschodniosłowiańskich, które od zarania traktowane były przez historiografię rosyjska jako jeden „naród” lub „bratnie narody” oraz legitymizuja tezę o wspólnym rodowodzie Słowian wschodnich, która przez wieki stanowiła oręż ideologiczny dający Moskwie prawo do roszczenia sobie pretensji w stosunku do Ukrainy oraz Białorusi. Poza tym autorzy podręcznika twierdza, że w okresie istnienia jednego organizmu politycznego, jakim była Ruś, ukształtowała się i w obliczu niebezpieczeństw konsolidowała „staroruska narodowość” składająca się z trzech komponentów: rosyjskiego, ukraińskiego oraz białoruskiego. Jej wyznacznikami miały być język oraz wiara chrześcijańska ${ }^{47}$.

Współczesna narracja podręcznikowa natomiast na XV wiek datuje powstanie narodowości ukraińskiej (zaznaczając jednocześnie, że proces ten rozpoczął się wcześniej) ${ }^{48}$. Sygnalizując pojawienie się i proces kształtowania narodowości ukraińskiej autorzy wyliczaja czynniki sprzyjajace oraz przyspieszające ów proces - były to m.in. język, religia prawosławna oraz prześladowania ze strony państwa polskiego zaprezentowanego jako aparat ucisku. Obraz Polski i relacje polsko-ukraińskie sa ukazane w sposób skrajnie jednostronnie negatywny. W podręczniku dla klasy siódmej sporo miejsca poświęcono prześladowaniom oraz dyskryminacji, jakiej poddana była ówczesna ludność ukraińska w granicach I Rzeczypospolitej. Był to potrójny rodzaj ucisku: ekonomiczny (system pańszczyźniany i wyzysk chłopstwa ukraińskiego przez polskie ziemiaństwo), polityczny czy narodowy (dyskrymi-

45 Путин предложил создать в Херсонесе русскую Мекку 18.08.2017, https:/ / lenta. ru/news/2017/08/18/mekka/ [dostęp: 19 października 2018].

46 Ibidem, s. 27.

47 Ibidem, s. 70.

48 История России. 7 класс. Уиебник для общеобразовательных организаций, red. А.В. Торкунов, ч. 2, s. 67. 
nacja ukraińskiej kultury, języka, polonizacja) oraz religijny. Państwo polskie, zgodnie $z$ narracja, było największą bariera na drodze rozwoju tożsamości „bratniego narodu”, a jej spoiwem wiara prawosławna ${ }^{49}$.

Kluczowym wydarzeniem, jednocześnie wywołującym wiele sporów pomiędzy historykami obu stron, jest Ugoda Perejasławska oraz postać samego Bohdana Chmielnickiego - jego rzeczywiste interesy oraz pobudki, jakimi się kierował, zwracając Ukrainę w stronę Rosji. W podręczniku dla klasy siódmej dominuje teza, że zjednoczenie obu, niegdyś stanowiących jeden organizm, państw było pragnieniem, ziszczeniem odwiecznego przeznaczenia Ukraińców, którzy, będąc wyobcowana i marginalizowana grupa w państwie polskim, pragnęli powrócić do macierzy - Matuszki Rosji.

Na plan pierwszy w opisie wydarzeń Rady Perejasławskiej wysuwa się mit o przyjaźni dwóch bratnich narodów, który był szczególnie lansowany w okresie sowieckim ${ }^{50} \mathrm{i}$ który jest mitem przewodnim obecnego podręcznika. „Putinowska” narracja podręcznikowa nawiąuje do spuścizny historiografii sowieckiej także poprzez prezentowanie sojuszu Kijowa $z$ Moskwa jako punktu kulminacyjnego ukraińskich dziejów narodowych ${ }^{51}$.

Pomimo wielu odniesień do stereotypów i mitów sowieckiej historiografii, która negowała suwerenność ukraińskiej wizji dziejów, natomiast inkorporowała ją do własnej historii, autorzy podręcznika zdecydowali się zrezygnować ze stosowania terminu wossojedinienie (воссоединение), czyli zjednoczenie, które było chętnie wykorzystywane w literaturze popularnonaukowej okresu sowieckiego. We współczesnej narracji użyto innych sformułowań - dominuje termin „wejście w skład Rosji”, ale pojawia się także określenie stosowane w minionej epoce - „oddanie się Ukrainy w poddaństwo Gosudarowi”52.

Terminy te wbrew pozorom sa niezwykle istotne i świadcza o „kondycji" rosyjskiej świadomości historycznej, a także rosyjskiego imperializmu. Termin wossojedinienie pojawił się pierwszy raz w książce Kiriłła Osipowa ${ }^{53}$ nieprzypadkowo. Autor zapożyczał do biografii het-

49 Ibidem, s. 67-68.

50 С. Екельчик, Імперія пам'яті. Російсъко-украйнсъкі стосунки в радянській історичній уяві, Критика, Київ 2008, s. 174-175.

51 Ibidem, s. 71.

52 История России. 7 класс. Уиебник для общеобразовательных организаций, red. А.В. Торкунов, ч. 2, s. 70-71.

53 Kiriłł Osipow (Кирим^ Осипов) - właśc. Iosif Mironowicz Kuperman (Иосиф Миронович Куперман) był sowieckim pisarzem, krytykiem literackim, doktorem nauk historycznych. Urodził się w 1900 r. w mieście Nikołajewie, a następnie przeprowadził się do Odessy. Należał do Stowarzyszenia Pisarzy ZSRS. Jego najpopularniejsze dzieła to biografie: Bohdan Chmielnicki oraz Aleksander Wasilewicz Suworow. 
mana Chmielnickiego opisy i fakty $z$ rosyjskiej dziewiętnastowiecznej historiografii, zwłaszcza $z$ Kostomarowa. Ukraina „oddała się w poddaństwo Rosji" - to typowy dla ówczesnej historiografii rosyjskiej pogląd. Pojęcie „zjednoczenia” ma ten sam rodowód. Rosyjscy imperialni historycy postrzegali Ugodę Perejasławska w kategoriach powrotu dawnych rosyjskich włości i uważali Ukraińców tylko za „małorosyjskie plemię/szczep" rosyjskiego narodu ${ }^{54}$. Dlatego stosowanie tego czy innego określenia w stosunku do opisu rezultatów Rady Perejasławskiej ma fundamentalne znaczenie. We współczesnej narracji podręcznikowej Ukrainie przyznano podmiotowość, a Ukraińcom status oddzielnego narodu, aczkolwiek wciąż posiadającego wspólne $z$ rosyjskimi współbraćmi korzenie.

W opisie Rady Perejasławskiej istotny jest także wizerunek samego Bohdana Chmielnickiego. Jawi się on mężem opatrznościowym, ojcem narodu, bohaterem narodowym i jedynym hetmanem, który pojmował prawdziwy interes narodu ukraińskiego jako zjednoczenie dwóch „bratnich narodów” oraz konieczność ich życia w symbiozie. Podręczniki utrwalają obraz Chmielnickiego jako polityka całkowicie prorosyjskiego $\mathrm{w}$ rosyjskich objęciach szukajacego schronienia oraz pomocy, a w rosyjskim carze widzącego swego protektora i władcę, który jest w stanie zjednoczyć Ukrainę i ją chronić. Zgodnie $z$ narracją zaprezentowana $\mathrm{w}$ podręczniku tylko żyjąc w zjednoczeniu $\mathrm{z}$ rosyjskim „bratnim narodem”, Ukraina mogła zachować i rozwijać swoją tożsamość narodowa. Uwage zwraca fakt wyciszania lub po prostu przemilczania konfliktów oraz nieporozumień, które pojawiały się na linii Kijów - Moskwa.

Natomiast na czele niechlubnego panteonu „antybohaterów” stanął hetman Iwan Mazepa, do którego w podręczniku wydawnictwa Proswieszczenie przeznaczonego dla klasy ósmej szkoły średniej przylgnęła etykieta „zdrajcy”, „wiarołomcy” i „sprzedawczyka” utrwalona jeszcze $\mathrm{w}$ dziewiętnastowiecznej historiografii, ale promowana też przez historiografię sowiecka. W narracji istotny jest sam opis bitwy pod Połtawa ${ }^{55}$, gdyż pozwolił on autorom podręcznika zaakcentować „przyjaźń dwóch bratnich narodów”. $Z$ górnolotnych sformułowań czytelnik dowiaduje się, że naród ukraiński nie przystał do zdrajcy, lecz pozostał wierny przysiędze przyjaźni oraz jedności z narodem rosyjskim. Wsparcie prostego ludu - walczącego przeciwko najeźdźcom szwedzkim - przechyliło szalę zwycięstwa na stronę cara Piotra Wiel-

54 С. Екемьчик, Iмперія..., s. 166-167.

55 Bitwa pod Połtawa - starcie zbrojne, które miało miejsce 8 lipca 1709 roku na terytorium ówczesnej Ukrainy Lewobrzeżnej, stoczone między wojskami szwedzkimi króla Karola XII a siłami rosyjskim i cara Piotra I. 
kiego. Akcent położono na skalę poparcia, jakim rzekomo wśród ludności ukraińskiej miała cieszyć się polityka Moskwy. Czytelnik odnosi wrażenie, że owo poparcie miało charakter powszechny ${ }^{56}$.

Śledzac kluczowe, a zarazem wywołujące spory między Kijowem a Moskwa, wydarzenia $z$ historii Ukrainy należy zwrócić także uwagę na początek XX wieku, zwłaszcza okres rewolucji październikowej i powstanie Ukraińskiej Republiki Ludowej, a także na jedno $z$ najbardziej dramatycznych wydarzeń I połowy XX stulecia, jakim był Wielki Głód lat 1932-1933.

W listopadzie 1918 roku powołano do życia Ukraińską Sowiecką Republikę: „[...] jednak 14 grudnia 1918 r. władzę w Kijowie przejął burżuazyjno-nacjonalistyczny Dyrektoriat ${ }^{57}$ na czele $z$ Wynniczenką i Petlurą" - tak czytamy w podręczniku dla klasy dziesiątej. W kompendium pominięto milczeniem fakt podpisania sojuszu wojskowego pomiędzy Symonem Petlura a Józefem Piłsudskim, co pozwoliło autorom nazwać wojska polskie, które wkroczyły na Ukrainę, okupacyjnymi ${ }^{59}$.

Kolejnym elementem przykuwajacym uwage czytelnika jest uwypuklanie poparcia, jakim rzekomo miała się cieszyć władza bolszewicka wśród ludności ukraińskiej. Autorzy podręcznika wiele razy podkreślaja brak aprobaty dla polityki Rady Centralnej i Dyrektoriatu oraz wrogi stosunek do „polskiego najeźdźcy”60.

Brak informacji o sojuszu polsko-ukraińskim oraz wyeksponowanie poparcia społecznego, jakim cieszyła się nowa władza bolszewicka, wysuwaja na plan pierwszy mit o dozgonnej przyjaźni dwóch narodów. Pomijanie pewnych istotnych i zmieniających wydźwięk wydarzeń konserwuje ów mit, a także w jednej linii frontu stawia naród ukraiński oraz rosyjski walczace najpierw $z$ „białym wrogiem” a następnie $z$ „pańską Polska”. Zgodnie $z$ narracja podręcznikową obraz bratniej przyjaźni jest nieskazitelny, niczym niezachwiany. Społeczeństwo ukraińskie bezgranicznie tej przyjaźni i przysiędze złożonej w 1654 roku jest wierne.

Wydarzeniem, które odcisnęło głębokie piętno na ukraińskiej tożsamości narodowej, był Wielki Głód lat 1932-1933. Dlatego też wokół

56 История России. 8 класс. Учебник для обиеобразовательных организаиий, red. А.В. Торкунов, ч. 1, Просвещение, Москва 2016, s. 28-29.

57 Należy zaznaczyć, że w podręczniku wspomniano o utworzeniu Ukraińskiej Republiki Ludowej oraz Ukraińskiej Socjalistycznej Republiki Sowieckiej, nie ma natomiast informacji o powołaniu Zachodnioukraińskiej Republiki Ludowej.

58 История России. 10 класс. Учебник для обиеобразовательных организаиий, red. А.В. Торкунов, ч. 1, Просвещение, Москва 2016, s. 73.

59 Ibidem, s. 65.

60 Ibidem, s. 74. 
niego władze ukraińskie starają się zrekonstruować ukraińską tożsamość narodowa, traktując je jako ucieleśnienie martyrologii narodu ukraińskiego.

W obecnie obowiązujacym podręczniku dla klasy dziesiątej, opracowanym pod redakcja Anatolija W. Torkunowa, kwestii Wielkiego Głodu poświęcono niewiele miejsca - zaledwie pół strony. Poprzedzaja go tematy rozkułaczania i powszechnej kolektywizacji ${ }^{1}$. Klęskę głodu rozpatruje się w podręczniku w sposób generalny, bez podziału na poszczególne regiony Związku Sowieckiego. Jest ona traktowana w kategoriach „ogólnopaństwowych”, tzn. jako zjawisko, które dotknęło Związek Sowiecki jako całość. O sytuacji na Ukrainie wspomina się tylko raz i to w sposób zbiorowy. Autorzy podręcznika przyczyn głodu lat trzydziestych upatruja w nieprzemyślanej polityce władz oraz zbyt szybkim tempie kolektywizacji rolnictwa. Liczbę ofiar głodu szacuje się na około $7 \mathrm{mln}$ dla całego Związku Sowieckiego ${ }^{62}$.

Interpretacja przyczyn Wielkiego Głodu lat trzydziestych XX wieku zaprezentowana w podręczniku nawiązuje do narracji utrwalonej jeszcze w okresie sowieckim, zgodnie $z$ która głód ten był konsekwencja źle zaplanowanej polityki kolektywizacji rolnictwa pogłębiona klęska nieurodzaju. Narracja ta konsekwentnie pomniejszała zakres odpowiedzialności władz za tą zbrodnię. Rosyjscy historycy także i dzisiaj twierdza, że była to wspólna tragedia i rozpatruja ja w kategoriach ogólnopaństwowych, podkreślając jednocześnie, że wspólne nieszczęście powinno jednoczyć, a nie dzielić.

W rosyjskiej narracji historycznej szczególne miejsce zajmuje Wielka Wojna Ojczyźniana. W podręczniku dla klasy dziesiątej w jego drugiej części, zgodnie $z$ kanonami sowieckiej historiografii, podkreślono mit „drużby narodów”. Znaczny nacisk położono na zaakcentowanie wspólnej walki narodu sowieckiego o wolność i niepodległość jedynej ojczyzny - Związku Sowieckiego. Wojna stała się bowiem czynnikiem konsolidującym naród sowiecki i wbrew oczekiwaniom niemieckiego okupanta nie spowodowała rozkładu państwa. W celu walki ze wspólnym nazistowskim wrogiem stworzono dziesiątki narodowych dywizji i brygad, w których ramię w ramię $z$ Rosjanami, Ukraińcami i Białorusinami walczyli przedstawiciele innych narodów. Za heroizm oraz męstwo 2069 Ukraińców zostało uhonorowanych tytułem Bohatera Związku Sowieckiego ${ }^{63}$. W tym znaczeniu autorzy podręcznika uwy-

61 Ibidem, s. 137-138.

62 Ibidem, s. 138.

63 История России. 10 класс. Учебник для общеобразовательных организаиий, red. А.В. Торкунов, ч. 2, Просвещение, Москва 2016, s. 51-52. 
puklili te działania oraz wydarzenia historyczne, które maja na celu zaprezentowanie narodu sowieckiego jako skonsolidowanego, wręcz pozbawionego wewnętrznych „rys” i „pęknięć”, konstruktu. Drużba narodów jawi się jako stabilna, niczym niezachwiana. Nawet wątki poświęcone ruchom narodowym, jak powołanie Organizacji Ukraińskich Nacjonalistów (OUN) a następnie Ukraińskiej Powstańczej Armii (UPA) nie przyćmiewaja tego mitu oraz ogólnego wrażenia czytelnika o powszechnej zgodzie i przyjaźni narodów tworzących Związek Sowiecki. Odpowiedzialność za powstawanie ruchów narodowych oraz współpracę z III Rzeszą złożono na barki panujących warunków podczas wojny i radykalizację nastrojów społecznych ${ }^{64}$.

Wątki dotyczace Ukrainy znajdujemy także w trzeciej części podręcznika dla klasy dziesiątej, które poświęcone sa jej postsowieckiej historii. Zgodnie $z$ narracja podręcznikową ukraińska Rada Najwyższa uchwaliła Akt Niepodległości Ukrainy 25 sierpnia 1991 roku $^{65}$. Następnie 1 grudnia 1991 roku przeprowadzono referendum, podczas którego 90,32 proc. głosujących opowiedziało się za niepodległym państwem ukraińskim ${ }^{66}$.

Istotnym wydarzeniem w ukraińskiej współczesnej historii była pomarańczowa rewolucja, która w omawianym podręczniku wydawnictwa Proswieszczenie została zaprezentowana jako kolejna próba izolowania Rosji od jej najbliższych sąsiadów za pomoca „pomarańczowych" i innych kolorowych "rewolucji” ${ }^{2}$. Za tymi działaniami stoja zachodni partnerzy - Stany Zjednoczone, Unia Europejska oraz NATO, którzy doprowadzili do anulowania wyników ukraińskich wyborów prezydenckich w 2004 roku. W rezultacie miejsce zwycięscy Wiktora Janukowycza, popierającego zacieśnianie współpracy z Rosja, zajał Wiktor Juszczenko dążacy do akcesji Kijowa do NATO. Zgodnie $z$ podręcznikową narracją, plany ukraińskich władz na czele $z$ Juszczenka, żeby przeprowadzić wspólnie $z$ Sojuszem Północnoatlantyckim wojenne manewry, spotkały się $z$ masowymi protestami ukraińskiego społeczeństwa. Poza tym odmowa ukraińskiego rzadu kupowania rosyjskiego gazu po cenach rynkowych doprowadziła do wielokrotnych przerw w dostawach surowca zachodnioeuropejskim konsumentom.

64 Ibidem, s. 53-54.

65 Datę 25 sierpnia 1991 roku podano w podręczniku jako dzień uchwalenia Aktu Niepodległości Ukrainy, podczas gdy Akt ten został przyjęty dzień wcześniej - 24 sierpnia 1991 roku. Dzień ten jest obecnie świętem państwowym - Świętem Niepodległości Ukrainy.

66 История России. 10 класс. Учебник для обиеобразовательных организаиий, red. А.В. Торкунов, ч. 3, Просвещение, Москва 2016, s. 40.

67 Ibidem, s. 96. 
W okresie prezydentury Wiktora Juszczenki ukraińskie władze ignorowały również interesy milionów własnych obywateli coraz intensywniej wypierając język rosyjski ze środków masowej informacji, kinematografii, systemu szkolnictwa ${ }^{68}$. Zdaniem autorów podręcznika, $z$ roku na rok kulturowe kontakty $z$ Rosją były ograniczane ${ }^{69}$.

Watki poświęcone historii Ukrainy w podręczniku wydawnictwa Proswieszczenie kończa się wraz z aneksja przez Rosję Krymu w 2014 roku - przy czym wydarzenie to określono mianem "zjednoczenia” (ros. воссоединение). Zgodnie $z$ podręcznikowa narracja, w warunkach ostrego politycznego kryzysu w 2014 roku na Ukrainie do władzy doszli nacjonaliści. W rezultacie nastapiło obalenie legalnie wybranego prezydenta Wiktora Janukowycza. Kijowskie władze zaczęły skłaniać się do zniesienia ustawy o statusie języka rosyjskiego jako regionalnego, co, zdaniem autorów, oznaczałoby faktyczny zakaz posługiwania się nim. W odpowiedzi na działania nowych ukraińskich władz ludność południowych i wschodnich regionów Ukrainy wystapiła o ochronę swoich praw. Taka forma „ochrony praw” ludności rosyjskojęzycznej jawi się referendum zorganizowane na Krymie, w którym zgodnie $z$ podręcznikową narracja 96,77 proc. mieszkańców Krymu oraz 95,6 proc. Sewastopola opowiedziało się za zjednoczeniem z Rosja. W wyniku referendum została przyjęta deklaracja o państwowej niepodległości Autonomicznej Republiki Krymu oraz miasta Sewastopola i podpisanie porozumienia $z$ Rosja o wejściu w jej skład. Po przyjęciu przez Dumę Państwową oraz Radę Federacji stosownych zmian prawnych prezydent Putin podpisał dokument o przyjęciu półwyspu w skład Federacji Rosyjskiej ${ }^{70}$.

Wydarzenia na Ukrainie i zjednoczenie Krymu z Rosja wywołały ostre reakcje USA oraz Unii Europejskiej, które przyjęły wymierzone w FR sankcje. Jednak, jak podkreślaja autorzy, nie spowodowało to zmiany obranego kursu rosyjskiej wewnętrznej i zagranicznej polityki ${ }^{71}$.

68 Należy zaznaczyć, iż kwestia ochrony praw ludności rosyjskojęzycznej oraz generalnie diaspory rosyjskiej zamieszkujacej byłe sowieckie republiki jest tematem zajmujacym poczytne miejsce w podręczniku. Nowo powstałe państwa po rozpadzie ZSRS charakteryzowała wewnętrzna niestabilność, w konsekwencji często naruszane były w nich prawa człowieka, w szczególności prawa rosyjskojęzycznych obywateli. Podkreślany jest fakt, że w okresie prezydentury Władimira Putina ochrona praw oraz interesów rosyjskich obywateli i rosyjskojęzycznej ludności za granica nabrała szczególnego znaczenia, stając się znaczącym obszarem rosyjskiej polityki zagranicznej. Zob. История России. 10 класс. Учебник для общеобразовательных организаиий, red. А.В. Торкунов, ч. 3, s. 38, 92.

69 Ibidem, s. 94.

70 Ibidem, s. 104-105.

71 Ibidem, s. 105. 


\section{PODSUMOWANIE}

Po analizie wybranych aspektów ukraińskich dziejów przedstawionych $\mathrm{w}$ rosyjskich podręcznikach dla szkoły średniej wydawnictwa Proswieszczenie należy stwierdzić, że Ukraina nadal odgrywa niezwykle istotna rolę w rosyjskiej historii oraz tożsamości. Naród ukraiński przestał być traktowany jako rosyjski subetnos, a ukraiński język jako dialekt posiadającego właściwości internacjonalizujące języka rosyjskiego. W podręczniku mówi się o kształtowaniu narodu ukraińskiego jako niezależnego tworu. Jednak uwzględniając kontekst, czasami fakt ten akcentuje się silniej - zwłaszcza w relacjach $z$ Polska - w celu podkreślenia odmienności kulturowej, religijnej oraz cywilizacyjnej między Ukraińcami a Polakami. Czasami natomiast ukraiński proces narodowotwórczy spychany jest na dalszy plan, tak jak w przypadku narracji opisujacych funkcjonowanie Ukrainy w granicach Rosji. W odniesieniu do relacji $z$ Rosją autorzy podręcznika nacisk kłada raczej na czynniki jednoczące oba narody - wspólne pochodzenie, religia, kultura, zbliżone języki oraz wspólna historia. Na zasadzie kontrastu $z$ Polską budowana jest bezpośrednia łączność oraz nierozerwalna więź przyjaźni pomiędzy dwoma słowiańskimi „bratnimi narodami”.

Sam podręcznik jest próbą unifikacji dwóch głównych tradycji historiograficznych imperialnej Rosji: dziewiętnastowiecznej i sowieckiej oraz dwóch koncepcji dziejów narodowych - podejścia państwowego a także cywilizacyjnego. Narracja podręcznikowa czerpie główne myśli, nurty, idee $z$ historiografii sowieckiej i jej poprzedniczki w dobie caratu. Stanowi synteze, a wręcz hybrydę obu imperialnych Rosji. Odżywaja więc koncepcje ideologiczne oraz polityczne, które funkcjonowały $\mathrm{w}$ rosyjskiej historiografii od wieków, a które były tworzone na zamówienie i potrzeby wielonarodowego imperium, legitymizując $\mathrm{w}$ ten sposób jego kolejne podboje terytorialne. Państwo to stanowi zarazem swoistą pancywilizację, która konsoliduje nie tylko jego wielonarodowe społeczeństwo (również dzisiaj), ale przekracza granice państwowe, inkorporujac dziedzictwo sąsiedniej Ukrainy czy Białorusi.

Zastosowanie cywilizacyjnej interpretacji dziejów państwa rosyjskiego powoduje, że szlak dziejów narodu ukraińskiego jest sprowadzany do „wiecznej przyjaźni” z narodem rosyjskim, która ma stanowić jego odwieczny cel oraz przeznaczenie. Zjednoczenie narodu ukraińskiego z rosyjskim „starszym bratem” stanowi kulminację ukraińskiego procesu historycznego. W ten sposób podmiotowość Ukrainy, chociaż w narracji podręcznikowej uznawana, jest jednocześnie kon- 
sekwentnie pomniejszana, a jej autonomia historyczna ograniczana. Koncepcja cywilizacyjna inkorporuje $\mathrm{w}$ ten sposób historię państwa i narodu ukraińskiego, włączając ją w dominujący nurt historii sowieckiej/rosyjskiej, przekształcając ją w jeden $z$ wielu jej „dopływów”.

Paradoksalnie pomimo aneksji Krymu oraz wojny z Kijowem wciąż jest pielęgnowany przewodni mit podręcznika, którym jest idea „przyjaźni dwóch bratnich narodów". W tym celu wszelka rozbieżność interesów, konflikty na linii Kijów - Moskwa sa albo wyciszane, albo po prostu przemilczane. Wydarzenia ze wspólnej historii sa selektywnie dobierane w taki sposób, aby ów mit legitymizowały. Narracja podręcznikowa przybiera jednak bardziej konfrontacyjny i podążajacy za medialna propaganda charakter $\mathrm{w}$ stosunku do najnowszej historii Ukrainy - po 1991 roku. Aczkolwiek pomimo otwartej wojny militarnej, gospodarczej, czy wojny pamięci, a wręcz i wojny cywilizacyjnej, mity o wspólnym rodowodzie, wspólnocie wiary i krwi są wciąż żywe w rosyjskiej świadomości, a Ukraina nie przestała być jej częścią.

Na przykładzie historii Ukrainy doskonale widać, że we współczesnej Rosji wciąż dominuje dyskurs imperialistyczny, dyskurs wielkiej Rosji, która próbuje narzucić innym narodom swoja pamięć oraz interpretację dziejów. Próbując stworzyć jedynie słuszna, kanoniczna wersję historii i eksportując ja na inne narody, Rosja stara się zbudować metapamięć, metatożsamość historyczna, która by wciąż stanowiła spoiwo „trzech bratnich narodów”, zachowując jednocześnie pozycje „starszego brata”.

Ujęcie historii Ukrainy w omawianych podręcznikach pokazuje, że pomimo werbalnych deklaracji idea narodu politycznego w Rosji jest nadal nieatrakcyjna. Podejmowane próby w tej dziedzinie przegrywaja $\mathrm{w}$ konfrontacji $\mathrm{z}$ imperialnym ujęciem rosyjskiej historii, które dominuje także w narracji podręcznikowej wydawnictwa Proswieszczenie. Formalne odwoływanie się do koncepcji narodu politycznego w dyskursie publicznym w Rosji oraz podczas opracowywania nowych podręczników do historii pokazuje, że jest ona traktowana przez władze raczej jako polityczny slogan wykorzystywany na potrzeby wewnętrzne. Jest ona nie tylko nieatrakcyjna wśród politycznej elity Rosji, ale również „kłóci się” $z$ rosyjska mapa mentalna, która wykracza daleko poza granice państwowe Federacji Rosyjskiej. 